\title{
ANALYSIS AND AUDIT OF KEY ECONOMIC INDICATORS OF ECONOMIC ENTITIES (A CASE STUDY OF THE DAIRY INDUSTRY)
}

\author{
Alla Savchenko', Kateryna Saliamon-Mikhieieva² \\ National University of State Fiscal Service of Ukraine, Ukraine \\ Marianna Holynska ${ }^{3}$ \\ Lviv University of Trade and Economics, Ukraine
}

\begin{abstract}
Instability of the environment and the lack of state support require economic entities to react instantly to its changes, only under such conditions the company will be able to survive and successfully operate in market relations. Economic and mathematical methods are an important tool for conducting qualitative analysis and audit, which enables to make well-grounded decisions. The purpose of the article is to study interrelation between the enterprise performance indicators, which are reflected in the enterprise financial statement, and factors of influence on the income from sales of products. The subject of the research is the theoretical and methodological basis of the use of mathematical modelling methods for the analysis and audit of key economic indicators of business entities on the example of the dairy industry. Methodology. To achieve this purpose, a system of general scientific and special methods is used. The research is carried out with the help of regression analysis, namely, the ridge regression, which distinguishes the influence of each factor in multicollinearity. Research results showed that among all factors, the greatest positive impact on the amount of revenue from sales belongs to the cost of production, indicating the rational use of resources, its increase leads to an increase in volumes of finished products, on which sales the company receives income. In the second place - the residual value of fixed assets, which characterizes their effective use in production activities. The third position is occupied by material costs. Practical implications. Accounts receivable has a negative impact and needs to be reviewed for its elimination and reduction. The volume of accounts receivable must correspond to the contractual discipline within the legal terms of the limitation period; only at such requirements, a positive effect on the financial status of the enterprise is possible. The problematic issue in the control over accounts receivable is the inability to receive transparent, relevant, and complete information about a business partner, which will be sufficient for conducting a qualitative analysis of settlements with debtors. This makes it impossible to predict the probability of the advent of the payment crisis of business entities, its prevention and elimination. Value/originality. The analysis and ranking of buyers, depending on the volume of purchases, the history of credit relations, and the proposed payment terms will increase the level of financial security of the enterprise; this measure will reduce the volume of bad debts. When entering into contracts of the purchase and sale of goods, works, and services, take into account the forecasts of cash receipts from debtors and prescribe penalties for considering the inflation component and taking into account the value of money in time. An increase in the number of customers of the enterprise products will reduce the risk of non-payment by one or more large customers. Consequently, the enterprise needs to update fixed assets and work to eliminate accounts receivable. Current liabilities have a negative impact, but their influence is negligible.
\end{abstract}

Key words: analysis, audit, accounts receivable, financial statement of enterprise, regression model.

JEL Classification: P51, M42, C24

\footnotetext{
Corresponding author:

${ }^{1}$ Department of Audit and Economic Analysis, National University of State Fiscal Service of Ukraine.

E-mail: ansavchenko@ukr.net

${ }^{2}$ Department of Audit and Economic Analysis, National University of State Fiscal Service of Ukraine.

E-mail: mihesha2006@ukr.net

${ }^{3}$ Department of State and Law Theory, Lviv University of Trade and Economics.

E-mail: holynska_m@ukr.net
} 


\section{Introduction}

The current development stage of the dairy industry in Ukraine is characterized by ambiguous production rates and the constant search for effective management options. The use of results of economic and mathematical modelling in the analysis and audit allows making managerial decisions reasonably, measuring the influence of the external and internal environment on the economic entity, evaluating risks of these decisions, and predicting their consequences.

The main problems in the market for milk and dairy products are: a low level of equipment with modern machinery; decrease in purchasing power of the population; unfavourable financial-credit and tax policy of the government; high labour and energy intensity of production and rapid product damage. Economicentities should look for internal reserves at the enterprise, use their strengths, and expand opportunities. Modelling is an effective means of solving these tasks and provides an important information base for conducting analytical research and audit examinations.

\section{Analysis of recent research and publications}

The use of regression analysis in the methodology of conducting an audit of financial and economic activity of the enterprise has already been considered in detail by Paianok T.M. who analysed the dynamics of the use of inventories and determined the factors of influence on their formation (Paianok, 2017). Rishchuk L.I. and Pobihun S.A. investigated the main risk-generating factors in the activity of oil refining enterprises, assessed the level of their impact on the profit of enterprises by using regression analysis (Rishchuk, Pobihun 2010). Stryhul L.S. defined and evaluated the investment attractiveness of the machine-building enterprise (Stryhul, 2012). On the basis of STATISTICA, Tarasevych A.P. investigated the economic state of confectionery enterprises in Ukraine (Tarasevych, 2004). Chukurna O.P. analysed the effect on the final price of the structure of costs of production and sales of machine-building products with the help of correlationregression analysis (Chukurna, 2016).

\section{The purpose and objectives of the research}

The main purpose of the study is to assess the impact of financial reporting articles of the enterprise on the income from the sale of products of the dairy enterprise by applying economic and mathematical methods.

The stated purpose forms the objectives: the disclosure of the main problems of agents of the dairy industry, the construction of a regressive model for evaluating each factor on the amount of income of the enterprise, identifying problem items of financial reporting, developing recommendations for reducing the negative impact of factors on the enterprise operation.
The information base is the statistical data of financial statements. Using the STATGRAPHICS Centurion program, the direction and the strength of the interrelation between statement items are investigated and a regression analysis is carried out.

\section{Presentation of the main research material}

Private households have a lion's share in providing the raw material base for dairy enterprises. The low solvency of economic entities as a result of the devaluation of the hryvnia leads to a decrease in purchasing prices for milk, on the one hand. On the other, the lack of motivation prompts the population to sell the livestock for meat. Hence, the milk market has a shortage of quality raw materials. State support, without which the economic development of the Ukrainian dairy industry is impossible, could change the situation.

Under these conditions, enterprises can rely only on their own capabilities; therefore, in order to increase the solvency of an entity, a special attention should be paid to its internal reserves. In addition to a detailed economic analysis, it is necessary to conduct a factor analysis that will reveal their impact on the enterprise's income. Getting the enterprise's maximum income is limited to the production costs, which are the main factors affecting its activities.

According to the statistical data of financial statements of PJSC "Zhytomyr Butter Plant" for a period of fifteen years, a regression analysis of its activity was carried out, where the performance characteristic is the product sales income $(\mathrm{Y})$ thousand $\mathrm{UAH}$, and the factor characteristics are: fixed assets (residual value) (X1); production cost (X2); receivables for goods, works, services: net realizable value (X3); other current receivables (X4); current liabilities (X5); material costs (X6); labour costs (X7), all indicators in thousand UAH. According to the results of the correlation matrix constructed, it is possible to determine which factors have the greatest influence on the income from sales of products (Table 1).

The correlation coefficient for other receivables has a negative sign indicating a reverse strong correlation, that is, the growth of this indicator negatively affects the revenue from the sale.

There is a close linear relationship between the model factors, which indicates the presence of multicollinearity. For confirmation, parameters of VIF (variance inflation factor) are calculated, the values of which by factors should be less than the limit $(\mathrm{VIF}=10$, at $\mathrm{p}=0,01)$ (Table 2) (Dudko, 2010).

Almost all calculated VIF estimates are bigger than the limit, the model has multicollinearity. For building a qualitative model, ridge regression is used as a possible means to eliminate multicollinearity and to determine the level of influence on the endogenous variable of each factor characteristic. The VIF parameter will have meaningful values for the ridge parameter $=0,02$ (Table 3 ). 
Table 1

Matrix of pair correlation coefficients

\begin{tabular}{|l|c|c|c|c|c|c|c|c|}
\hline \multicolumn{1}{|c|}{ Indicator } & $\mathrm{Y}$ & $\mathrm{X} 1$ & $\mathrm{X} 2$ & $\mathrm{X} 3$ & $\mathrm{X} 4$ & $\mathrm{X} 5$ & $\mathrm{X} 6$ & $\mathrm{X} 7$ \\
\hline Product sales income (Y) & 1 & 0,9443 & 0,9868 & 0,8017 & $-0,7638$ & 0,8760 & 0,9906 & 0,9660 \\
\hline Fixed assets (residual value) (X1) & 0,9443 & 1 & 0,8868 & 0,7406 & $-0,7131$ & 0,9132 & 0,9091 & 0,9241 \\
\hline Production cost (X2) & 0,9868 & 0,8868 & 1 & 0,8285 & $-0,7404$ & 0,8382 & 0,9955 & 0,9481 \\
\hline $\begin{array}{l}\text { Receivables for goods, works, } \\
\text { services (X3) }\end{array}$ & 0,8017 & 0,7406 & 0,8285 & 1 & $-0,5546$ & 0,8784 & 0,8347 & 0,8240 \\
\hline Other current receivables (X4) & $-0,7638$ & $-0,7131$ & $-0,7404$ & $-0,5546$ & 1 & $-0,7189$ & $-0,7350$ & $-0,7683$ \\
\hline Current liabilities (X5) & 0,8760 & 0,9132 & 0,8382 & 0,8784 & $-0,7189$ & 1 & 0,8592 & 0,9053 \\
\hline Material costs (X6) & 0,9906 & 0,9091 & 0,9955 & 0,8347 & $-0,7350$ & 0,8592 & 1 & 0,9557 \\
\hline Labour costs (X7) & 0,9660 & 0,9241 & 0,9481 & 0,8240 & $-0,7683$ & 0,9053 & 0,9557 & 1 \\
\hline
\end{tabular}

Source: built by the authors according to the data (Paianok, 2017)

Table 2

\section{VIF parameter calculation}

\begin{tabular}{|l|c|}
\hline \multicolumn{1}{|c|}{ Model parameters } & VIF \\
\hline Fixed assets (residual value) (X1) & 20,6094 \\
\hline Production cost (X2) & 160,394 \\
\hline Receivables for goods, works, services (X3) & 12,4715 \\
\hline Other current receivables (X4) & 3,50567 \\
\hline Current liabilities (X5) & 25,8943 \\
\hline Material costs (X6) & 190,651 \\
\hline Labour costs (X7) & 18,5949 \\
\hline
\end{tabular}

Source: calculated by the authors according to (Chukurna, 2016)

Table 3

Ridge regression of the dependence of income on sales and selected factors for the ridge parameter of 0.02

\begin{tabular}{|l|c|c|}
\hline \multicolumn{1}{|c|}{ Parameter } & Estimate & VIF \\
\hline Constant & 39554,2 & - \\
\hline Fixed assets (residual value) (X1) & 1,4159 & 6,2428 \\
\hline Production cost (X2) & 0,5050 & 4,8740 \\
\hline Receivables for goods, works, services (X3) & $-0,6319$ & 4,3178 \\
\hline Other current receivables (X4) & $-21,3685$ & 2,3549 \\
\hline Current liabilities (X5) & $-0,0421$ & 6,8402 \\
\hline Material costs (X6) & 0,5205 & 4,8498 \\
\hline Labour costs (X7) & 1,9501 & 8,7336 \\
\hline
\end{tabular}

Source: calculated by the authors according to the official site of SMIDA (2018)

The constructed model has a high coefficient of multiple correlation $(\mathrm{r}=0,9955)$, which indicates a close linear relationship between the factors. Revenue from product sales by $99.097 \%$ depends on model factors and only by $0.9036 \%$ on other factors, including the stochastic variable $\left(\mathrm{R}^{2}=0,99097\right)$. The estimated value of the Durbin-Watson statistic - 1,28 that indicates the absence of auto-correlation ( $\mathrm{dl}=0,230$ $\mathrm{du}=1,015)$.

The calculated Fisher criterion - 335,7 with a significance of 2,25E-06 indicates the adequacy of the model $\left(\mathrm{F}_{\text {таб } .}=4,88\right.$, for $\left.\alpha=0,05\right)$.

The regression equation will appear as follows:

$$
\begin{aligned}
& Y=39554,2+1,4159 X_{1}+0,5050 X_{2}-0,6319 X_{3}- \\
& -21,3685 X_{4}-0,0421 X_{5}+0,5205 X_{6}+1,9501 X_{7} \cdot(1)
\end{aligned}
$$

A negative sign for parameters $\beta$ of accounts receivable for goods, work, services (X3), other current receivables
(X4) and current liabilities (X5) indicates the negative impact of these factors on sales revenue.

The calculated standardized coefficients (beta coefficients) make it possible to compare the effect of the explanatory variables on the volume of production stocks (Table 4).

At the enterprise, production cost has the greatest impact on the income from sales of products. On the second place - material costs, which is quite justified from an economic point of view. With a small gap, in the third place, there is the residual value of fixed assets. Labour costs occupy the fourth position. Accounts receivable for goods, works, services, other current receivables, and current liabilities have a negative impact on sales revenue and occupy positions 5, 6, and 7, respectively. A detailed step-by-step analysis of accounts receivable is required [8]. The elasticity coefficient is calculated: 
Table 4

Standardized regression coefficients

\begin{tabular}{|c|c|c|c|c|c|c|c|}
\hline $\begin{array}{c}\text { Ridge } \\
\text { parameter }\end{array}$ & $\mathrm{X} 1$ & $\mathrm{X} 2$ & $\mathrm{X} 3$ & $\mathrm{X} 4$ & $\mathrm{X} 5$ & $\mathrm{X} 6$ & $\mathrm{X} 7$ \\
\hline 0,0 & 0,2747 & 0,6584 & $-0,0734$ & $-0,0163$ & 0,0187 & 0,0577 & 0,0638 \\
\hline 0,005 & 0,2579 & 0,4693 & $-0,0639$ & $-0,0246$ & 0,0047 & 0,2421 & 0,0804 \\
\hline 0,01 & 0,2536 & 0,4202 & $-0,0571$ & $-0,0282$ & $-0,0005$ & 0,2777 & 0,0927 \\
\hline 0,015 & 0,2506 & 0,3949 & $-0,0516$ & $-0,0309$ & $-0,0027$ & 0,2900 & 0,1025 \\
\hline 0,02 & 0,2480 & 0,3784 & $-0,0470$ & $-0,03306$ & $-0,0034$ & 0,2948 & 0,1105 \\
\hline 0,025 & 0,2455 & 0,3662 & $-0,0429$ & $-0,0350$ & $-0,0033$ & 0,2964 & 0,1172 \\
\hline Place & 3 & 1 & 5 & 6 & 7 & 2 & 4 \\
\hline
\end{tabular}

Source: calculated by the authors according to the official site of SMIDA (2018)

$$
E_{y / x_{i}}=\beta_{i} \frac{\bar{x}_{i}}{\bar{y}}
$$

where $\beta$-regression equation parameters.

It allows more accurately measuring the effect of each factor on the endogenous variable (Figure 1).

Growth of the residual value of fixed assets by $1 \%$ leads to an increase in sales revenue by $27.3 \%$ (with a constant value of other factors), an increase by $1 \%$ : production cost will increase the endogenous variable by $34.9 \%$, material costs - by $26.2 \%$, labour costs by $12.5 \%$. An increase in accounts receivable for goods, works, services, other current receivables, and current liabilities by $1 \%$ will result in a decrease in revenues by $4.1 ; 2.0$; and $0.4 \%$, respectively.

\section{Conclusions}

Therefore, among all factors, the cost of production has the greatest positive impact on the amount of revenue from sales, indicating the rational use of resources, its increase leads to an increase in volumes of finished products, on which sales the company receives income. On the second place is the residual value of fixed assets, which characterizes their effective use in production activities. The third position is occupied by material costs. Labour remuneration occupies the fourth position - there is a system of stimulation at the enterprise, but its impact on sales revenue is insignificant (the average number of employees for this period did not change significantly). Under these circumstances, an increase in fixed assets is optimal for the enterprise.

Accounts receivable has a negative impact and needs to be reviewed for its elimination and reduction. The volume of accounts receivable must correspond to the contractual discipline within the legal terms of the limitation period; only at such requirements, a positive effect on the financial status of the enterprise is possible. The turnover rate of accounts receivable reduces balances on receivables for each date and vice versa. The problematic issue in the control over accounts receivable is the inability to receive transparent, relevant, and complete information about a business partner, which will be sufficient for conducting a qualitative analysis of settlements with debtors. This makes it impossible to predict the probability of the advent of the payment crisis of business entities, its prevention and elimination. The analysis and ranking of buyers, depending on the volume of purchases, the history of credit relations,

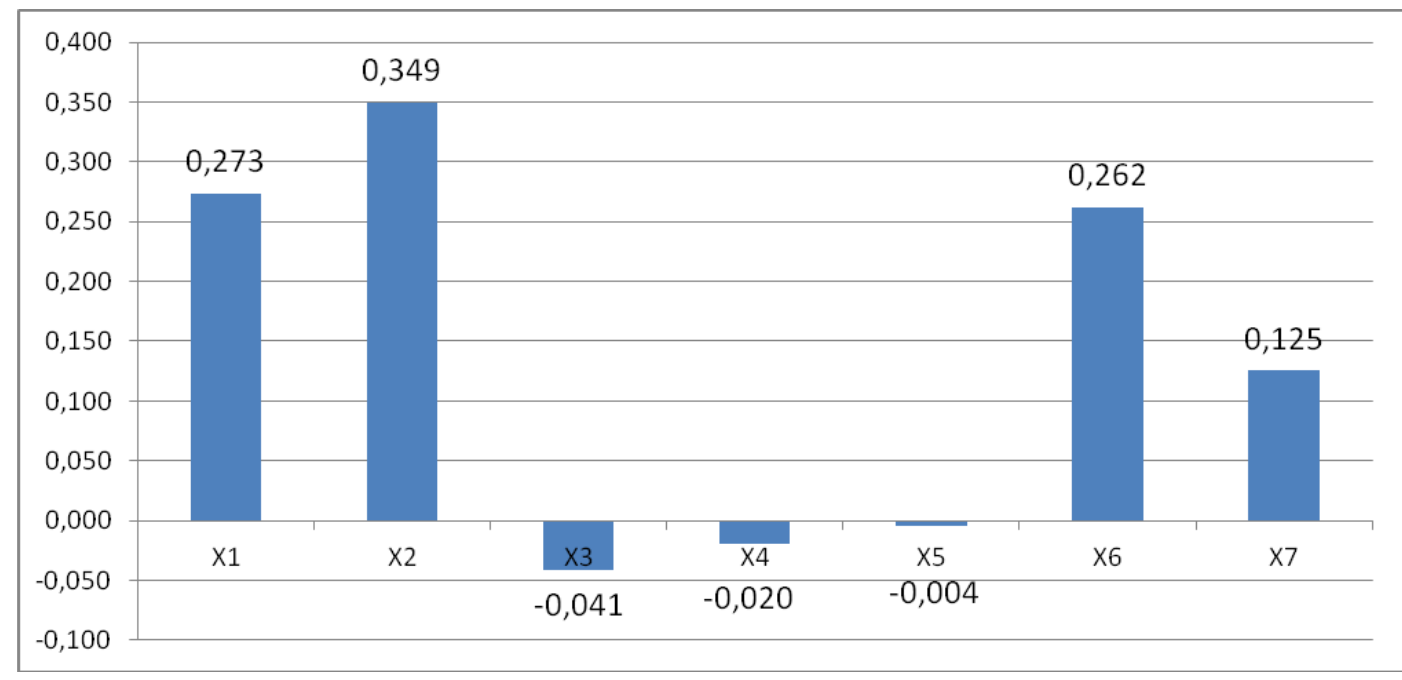

Figure 1. The elasticity of exogenous variables of the regression model Source: calculated by the authors according to the official site of SMIDA (2018) 
and the proposed payment terms will increase the level of financial security of the enterprise; this measure will reduce the volume of bad debts. When entering into contracts of the purchase and sale of goods, works, and services, take into account the forecasts of cash receipts from debtors and prescribe penalties for considering the inflation component and taking into account the value of money in time. An increase in the number of customers of the enterprise products will reduce the risk of non-payment by one or more large customers.

Consequently, the enterprise needs to update fixed assets and work to eliminate accounts receivable. Current liabilities have a negative impact, but their influence is negligible.

\section{References:}

Dudko V.S., Krasnova T.D., Lahovskyi V.V. (2010). Mathematical modelling in economics: study guide for students of HEI: in 2 parts. Irpin: NUDPSU, P. 1: Econometric models, 448 p.

SMIDA official site (2018). Databases. Public Joint-Stock Company “Zhytomyr Butter Plant”. Retrieved from: http://smida.gov.ua

Paianok T.M., Savchenko A.M. (2017). Analysis of accounts receivable of the enterprise using economic and mathematical methods. The Economist. № 3, pp. 27-32.

Paianok T.M. (2017). Regression analysis in the audit. Herald of KNUTE, № 1, pp. 117-126.

Rishchuk L.I., Pobihun S.A. (2010). Estimation of the influence of factors on the activity of oil refineries. Herald of Khmelnytskyi National University. Economic Sciences. Khmelnytskyi, №5, Vol. 1, pp. 195-199.

Stryhul L.S. (2012). Areas of application of correlation-regression analysis and coefficient method of financial analysis for estimation of investment attractiveness of an enterprise. Innovative Economy. № 12(38), pp. 258-264.

Tarasevych A.P. (2016). Economic condition monitoring system of the enterprise: extended thesis abstract for Cand. Sc. (Economics) : 08.00.04 / Tarasevych Anna Petrivna ; Odessa National Economic University, 20 p.

Chukurna O.P. (2016). Improvement of marketing pricing methods of machine-building enterprises. Economic Bulletin of National Technical University of Ukraine "Kyiv Polytechnic Institute". № 13, pp. 424-430. 